\title{
Continuous photoperiod of the Artic summer stimulates the photosynthetic response of some marine macrophytes
}

Marina Sanz-Martín ${ }^{1 *}$, Iris E. Hendriks ${ }^{1,2}$, Jacob Carstensen ${ }^{3 a}$, Núria Marbà ${ }^{1}$, Dorte Krause-Jensen ${ }^{3 b, 5}$, Mikael K. Sejr ${ }^{4}$, Carlos M. Duarte ${ }^{4,5}$

${ }^{1}$ Global Change Research Group, Mediterranean Institute of Advanced Studies (CSICUIB), Miquel Marquès 21, 07190 Esporles, Spain.

${ }^{2}$ Department of Biology, University of the Balearic Islands, Crta. Valldemossa, km 7.5, 07122 Palma, Spain.

${ }^{3 a}$ Department of Bioscience, Aarhus University, Frederiksborgvej 399, DK4000 Roskilde, Denmark.

${ }^{36}$ Department of Bioscience, Aarhus University, Vejlsøvej 25, DK-8600 Silkeborg, Denmark.

${ }^{4}$ Arctic Research Centre, Department of Bioscience, Aarhus University, C.F. Møllers Allé 8, DK-8000 Århus, Denmark.

${ }^{5}$ King Abdullah University of Science and Technology, Red Sea Research Center, Thuwal 23955-6900, Kingdom of Saudi Arabia.

*Corresponding author: marina@imedea.uib-csic.es, sanzmartin.marina@gmail.com

\begin{abstract}
Subarctic macrophytes are predicted to expand in the Arctic as a result of on-going global climate change. This will expose them to 24 hours of light during the Arctic summer while $p \mathrm{CO}_{2}$ levels are predicted to rise globally. Here, we tested the photosynthetic activity of two brown macroalgae (Ascophyllum nodosum, Fucus vesiculosus) and one seagrass (Zostera marina) from subarctic Greenland, measuring their relative maximum electron transport rate $\left(\mathrm{rETR}_{\max }\right)$, photosynthetic efficiency $(\alpha)$ and saturating irradiance $\left(\mathrm{I}_{\mathrm{k}}\right)$ after 3 days of incubation at different photoperiods $(12: 12 \mathrm{~h}, 15: 09 \mathrm{~h}, 18: 06 \mathrm{~h}, 21: 03 \mathrm{~h}$ and 24:00h, light:dark) with ambient values of $p \mathrm{CO}_{2}(200 \mathrm{ppm}$, characteristic of current subarctic surface waters) and increased $p \mathrm{CO}_{2}(400$ and $1000 \mathrm{ppm})$. The photosynthetic parameters $\mathrm{rETR}_{\max }$ and $\mathrm{I}_{\mathrm{k}}$ increased significantly with longer photoperiods and increased, however insignificantly, with increased $p \mathrm{CO}_{2}$. Responses differed between species. A. nodosum and Z. marina showed the highest increase of $\mathrm{rETR}_{\max }$ and $\mathrm{I}_{\mathrm{k}}$ from $12 \mathrm{~h}$ to $24 \mathrm{~h}$ while the increase of $F$. vesiculosus was smaller. Our results suggest that as subarctic macrophytes expand in the Arctic in response to retracting sea ice, the long summer days will stimulate the productivity of the species tested here, while the effect of high- $\mathrm{CO}_{2}$ environment needs further research.
\end{abstract}




\section{Highlights}

- Long photoperiods increase the photosynthetic activity of certain subarctic macrophytes

- Increased $\mathrm{CO}_{2}$ had no effect on tested macrophytes

- Highest increases of photosynthetic activity of Ascophyllum nodosum and Zostera marina at long day lengths; smaller increase for Fucus vesiculosus

- Subarctic macrophytes, expanding as sea ice retreats, will benefit from long summer days

\section{Keywords}

Macrophytes; subarctic; electron transport rate; continuous photoperiod and carbon dioxide.

\section{Introduction}

The presence of macroalgae assemblages in the Arctic is often limited by extended sea-ice cover that reduces submarine light penetration (Krause-Jensen et al., 2012; Krause-Jensen and Duarte, 2014; Wulff et al., 2009). However, an Arctic largely free of sea ice in summer, as predicted by the year 2037 (IPCC Panel, 2014; Wang and Overland, 2009), may favour the entrance of new species into the Arctic and the expansion of existing Arctic vegetation (Krause-Jensen and Duarte, 2014). Indeed, the northward extension range of macroalgae, mainly Phaeophyta, but also Chlorophyta and Rhodophyta has been observed around $78^{\circ} \mathrm{N}$ in Svalbard (Fredriksen et al., 2014). An increase of macrophyte biomass has also been detected together with the upward movement of sublittoral algal species to the littoral zone and a biodiversity increase in this Arctic region, likely related to climate warming (Weslawski et al., 2010). Arctic warming has already led to the reappearance of the blue mussel, Mytilus edulis, in Svalbard after 1,000 year absence (Berge et al., 2005) as well as an increase of the Arctic cod fishery due to the poleward expansion of cod habitat (Kjesbu et al., 2014). At a global scale, $75 \%$ of the range shifts studied in marine species, including macrophytes and phytoplankton among other taxa, are in poleward direction due to climate warming (Sorte et al., 2010).

Atmospheric carbon dioxide concentration has increased $\sim 40 \%$ since the beginning of the industrial era (Zeebe, 2012), currently exceeding $400 \mathrm{ppm}$. Yet, $p \mathrm{CO}_{2}$ in the Arctic Ocean ranks amongst the lowest values reported across the open ocean (Takahashi et al., 2009), presenting characteristically low $p \mathrm{CO}_{2}(<200 \mu \mathrm{atm})$ due to intense spring phytoplankton blooms (Bates et al., 2006; Fransson et al., 2009; Holding et al., 2015) and the influence of sea ice melting during summer (Rysgaard et al., 2009). 
Marine macrophyte communities tend to be autotrophic, where photosynthesis dominates over respiration (Duarte and Cebrián, 1996), thereby leading to a depletion of $\mathrm{CO}_{2}$, potentially reaching limiting $p \mathrm{CO}_{2}$ levels (Krause-Jensen et al., 2016; Mercado and Gordillo, 2011). In parallel, atmospheric $\mathrm{CO}_{2}$ is predicted to increase, reaching $1000 \mathrm{ppm}$ before the end of the century under some scenarios (IPCC Panel, 2014). Such levels may further stimulate submerged sub-arctic vegetation (Krause-Jensen and Duarte, 2014).

Most habitat-forming macroalgae in the Arctic are originally from North Atlantic and North Pacific regions (Wilce and Dunton, 2014; Wulff et al., 2009). Zostera marina has been reported in the Arctic up to $70^{\circ} \mathrm{N}$, although its presence is scarce (reviewed by Olesen et al., 2015). Intertidal belts of the macroalgae Ascophyllum nodosum are present up to $69.7^{\circ} \mathrm{N}$ (reviewed by Marbà et al., 2017) and Fucus vesiculosus has been found as far north of $75^{\circ} \mathrm{N}$ as the Svalbard Archipelago (Florczyk and Latala, 1989; Hansen and Haugen, 1989).

Warming and consequently retreating sea-ice is increasing the available habitat, leading to a forecasted expansion of subarctic and Arctic vegetation into the Arctic Ocean that would increasingly expose the vegetation to the extended daylight period of the Arctic summer (Krause-Jensen et al., 2016; Krause-Jensen and Duarte, 2014). Potentially, continuous daylight increases the hours of C-fixation through photosynthesis, increasing its primary productivity. However, the excess of light energy and long photoperiods might induce photoinhibition damage and prevent growth (Velez Ramirez et al., 2011). Therefore, studying the physiology and the photosynthetic machinery of subarctic marine macrophytes under a continuous photoperiod, characteristic of the Arctic summer, is key to evaluate the probabilities of a forecasted poleward expansion. Research on the effect of continuous light on photosynthetic organisms is scarce and has mainly been related to use in greenhouse food production (Velez Ramirez et al., 2011).

The physiological responses of a canopy-forming species to different levels of light intensity, $\mathrm{CO}_{2}$ and temperature has been evaluated in the Antarctica (Iñiguez et al., 2017). In the same region, the transition from late winter to summer on phytoplankton physiology has been evaluated focussing on variable light intensities (McMinn et al., 2010) in combination with increased $\mathrm{CO}_{2}$ (Hoppe et al., 2015). In the Arctic Ocean, the effect of increased $\mathrm{CO}_{2}$ has been physiologically tested in macroalgae (Iñiguez et al., 2016) and phytoplankton in combination with light intensity and temperature (Hoppe et al., 2018, 2017). The physiological responses of polar macro and microphytes to continuous photoperiod remains insufficiently explored. Krause-Jensen et al. (2016) concluded that day lengths longer than 21 hours, characteristic of Arctic summers, were conducive to sustain a high $\mathrm{pH}$ in seawater as a result of photosynthesis by macroautotrophs. They also concluded that experimental increase in $\mathrm{CO}_{2}$ concentration stimulated the capacity of macrophytes to deplete $\mathrm{CO}_{2}$. However, they analysed an assemblage of three species (Z. marina, A. nodosum and $F$. vesiculosus) and did not explore the species-specific response of photosynthetic physiology to longer photoperiods and increased $\mathrm{CO}_{2}$, neither the interactive effect between the day length and enhanced $\mathrm{CO}_{2}$, which are the aims of our study.

Marine macrophytes are often limited by $\mathrm{CO}_{2}$ because the boundary layers formed around the blades limit the entrance of $\mathrm{CO}_{2}$ by diffusion due to its thickness (Hendriks et 
129 al., 2017), which together with high primary productivity rates in densely vegetated areas

130 result in low $\mathrm{CO}_{2}$ levels close to the blade surface (Bowes and Salvuci, 1989; Holbrook

131 et al., 1987; Hurd et al., 2009). The low $\mathrm{CO}_{2}$ concentration characteristic of Arctic and

132 subarctic waters due to strong biological uptake in spring and melting sea ice in summer

133 (Bates et al., 2006; Fransson et al., 2009; Meire et al., 2015; Takahashi et al., 2009) may

134 cause $\mathrm{CO}_{2}$ limitation, - with the risk being particularly likely in vegetated coastal habitats

135 that represent hot spots of productivity and $\mathrm{CO}_{2}$-draw down. Productivity of subarctic

136 macrophytes could, hence, be limited by $\mathrm{CO}_{2}$ similar to the limitation of phytoplankton

137 productivity in the Arctic (Engel et al., 2014; Hein and Sand-Jensen, 1997; Holding et al.,

138 2015).

139 Key to understanding how marine vegetation will respond to predicted increased levels

140 of dissolved inorganic carbon (DIC) and longer photoperiods is their species-specific

141 photosynthetic physiology (Koch et al., 2013). The majority of autotrophs have a higher

142 photosynthetic affinity for $\mathrm{CO}_{2}$ than bicarbonate $\left(\mathrm{HCO}_{3}^{-}\right)$(Bowes, 1985; Madsen and

143 Sand-Jensen, 1991). In the oceans, an increase in $\mathrm{CO}_{2}$ concentration will increase the total

144 DIC and hydrogen ion concentration $\left(\mathrm{H}^{+}\right)$leading to a decrease in $\mathrm{pH}$ and a change in the

145 carbon species. The increase in $\mathrm{CO}_{2}$ availability will probably enhance photosynthesis

146 and growth of seagrasses and many macroalgae as well as the competition between

147 species and would benefit those with a greater ability to rapidly sequester $\mathrm{CO}_{2}$ (Koch et 148 al., 2013).

149 The majority of marine macroalgae and seagrass are supposed to possess Rubiscos that

150 are not saturated at the current ocean DIC concentration, thus these organisms have

151 Carbon Concentrating Mechanisms (CCMs), which finally increase $\mathrm{CO}_{2}$ around Rubisco

152 relative to the $\mathrm{CO}_{2}$ concentration in seawater, through an active transport of $\mathrm{CO}_{2}$ and/or

$153 \mathrm{HCO}_{3}$ - inside the cell (Giordano et al., 2005). Despite the widespread presence of CCMs,

154 different species-specific responses to increased levels of $\mathrm{CO}_{2}$ has been observed (Beer

155 et al., 2014; Beer and Rehnberg, 1997; Sand-Jensen and Gordon, 1984; Koch et al., 2013;

156 Surif and Raven, 1989). Many marine macrophytes possess the capacity to utilize $\mathrm{HCO}_{3}{ }^{-}$

157 for photosynthesis (Giordano and Maberly, 1989; Koch et al., 2013; Mercado et al., 2009;

158 Surif and Raven, 1989), although it does not indicate that their photosynthesis might be

159 saturated at present $\mathrm{CO}_{2}$ conditions. In fact, all analysed seagrass and most brown

160 macroalgae showed that an increase in DIC concentrations promotes higher

161 photosynthetic and growth rates (Koch et al., 2013). In conditions of severe $\mathrm{CO}_{2}$

162 limitation, the high availability of $\mathrm{HCO}_{3}{ }^{-}$increases $\mathrm{C}$ acquisition, but it is energetically

163 expensive and $\mathrm{CO}_{2}$ remains preferable for photosynthesis as compared to $\mathrm{HCO}_{3}{ }^{-}$due to

164 lower photosynthetic $\mathrm{K}_{0.5}$ values for $\mathrm{CO}_{2}$ than for $\mathrm{HCO}_{3}{ }^{-}$in seagrasses and macroalgae

165 (Sand-Jensen and Gordon, 1984).

166 The brown macroalgae $F$. vesiculosus is an exception, with photosynthetic rates being

167 saturated at current DIC levels (Koch et al., 2013; Raven and Osmond, 1992) and has a

168 high affinity and capacity for DIC uptake by non-diffusive mechanisms (Mercado et al.,

169 2009). Conversely, photosynthesis of A. nodosum is not $\mathrm{CO}_{2}$-saturated, even though its

170 capacity for $\mathrm{HCO}_{3}^{-}$-use has been demonstrated (Koch et al., 2013; Surif and Raven, 1989).

171 The utilization of $\mathrm{HCO}_{3}{ }^{-}$in seagrasses is generally less efficient than in macroalgae (Beer

172 et al., 2014; Beer and Rehnberg, 1997; Sand-Jensen and Gordon, 1984) although for $Z$. 
marina it is not confirmed whether photosynthesis is saturated at current $\mathrm{CO}_{2}$ levels

174 (Koch et al., 2013). A. nodosum, F. vesiculosus and Z. marina therefore represent 3 test organisms for which different responses to increased $\mathrm{CO}_{2}$ could be expected.

Polar macroalgae are generally hypothesized to have a competitive advantage in a future high $\mathrm{CO}_{2}$ environment (Raven et al., 2002a, 2002b). In cold regions the entry of $\mathrm{CO}_{2}$ by diffusion into the cell seems to be more widespread for brown and red macroalgae, than the same species of macroalgae in temperate regions, avoiding the need of CCMs and making them more prone to stimulation by increased $\mathrm{CO}_{2}$ than temperate macroalgae (Mercado and Gordillo, 2011; Raven et al., 2002a, 2002b), although higher $\mathrm{CO}_{2}$ dependence has been attributed to red polar macroalgae (Raven et al., 2002b).

Here we experimentally test the hypothesis that increased $\mathrm{CO}_{2}$ supply (400 and 1000 ppm) relative to the low ambient $\mathrm{CO}_{2}$ levels of Arctic waters (200 ppm) increase photosynthesis of subarctic marine macrophytes. Such an increase would support the projected expansion of marine vegetation in the future high Arctic given that photosynthetic activity of individual leaves is related with estimates of macrophyte productivity at a community-level (Silva et al., 2005). We also evaluate the effect of longer photoperiods $(12: 12,15: 09,18: 06,21: 03$ and 24:00 light:dark hours) on photosynthetic activity to assess whether long days/continuous daylight, as resulting from longer open water periods in the future Arctic, hamper or stimulate photosynthesis. We use two macroalgae species ( $A$. nodosum and $F$. vesiculosus) and one seagrass species $(Z$.

\section{Materials and methods}

\subsection{Experimental set-up and sampling}

Brown macroalgae ( $A$. nodosum, $F$. vesiculosus) fronds were collected in the lower intertidal zone and seagrass (Z. marina) shoots, sparse in this region (Olesen et al., 2015), were collected from shallow waters (1 to $3 \mathrm{~m}$ depth) at the central part of Kobbefjord (64ำ $10^{\prime} \mathrm{N}$ and $51^{\circ} 29^{\prime} \mathrm{W}$, Godthåbsfjord, Greenland) in early June 2014.

They were kept cool and humid during the $30 \mathrm{~h}$ transport by airplane to the laboratories of the Mediterranean Institute for Advanced Studies (IMEDEA, Mallorca, Spain). In the laboratory facilities they were acclimated in artificial seawater to the photoperiod to which they were exposed at collection $(21: 03 \mathrm{~h}$, light:dark hours, in the Godthåbsfjord in early June), during 10 days in a climate controlled room at $4{ }^{\circ} \mathrm{C}$.

After the acclimation period, undamaged tips of $A$. nodosum and $F$. vesiculosus and shoots of $Z$. marina were transferred into nine aquaria $(6 \mathrm{~L})$, with controlled photoperiod, temperature and $p \mathrm{CO}_{2}$ levels. The total biomass of macrophytes in each aquarium was 2.7-3.7 g dry weight (DW), yielding a biomass density of 0.45-0.61 $\mathrm{g} \mathrm{DW} \mathrm{L} \mathrm{DW}^{-1}$, mimicking dense vegetation. The aquaria were exposed to three $p \mathrm{CO}_{2}$ levels $(200,400$ and $1000 \mathrm{ppm}$ in the absence of macrophytes) with three replicated aquaria per level. $200 \mathrm{ppm}$ reflected contemporary $\mathrm{pCO}_{2}$ levels in subarctic surface waters in spring/summer in Godthåbsfjord, close to Kobbefjord (Meire et al., 2015). The highest $p \mathrm{CO}_{2}$ manipulation (1000 ppm) was set to the predicted scenario of atmospheric $p \mathrm{CO}_{2}$ by 2100 (IPCC Panel, 
217 2014), and $400 \mathrm{ppm}$ represented an intermediate level (Fig. 1). To mimic the

218 photosynthetic active radiation (PAR) within in situ canopies, the aquaria were 219 illuminated with $111 \pm 5 \mu \mathrm{mol}$ photons $\mathrm{m}^{-\mathrm{s}} \mathrm{s}^{-1}$ of PAR at the water surface using 2 lamps

220 with $54 \mathrm{~W}$ fluorescent tubes. This light level was about half of the maximum PAR 221 reported in Greenland fjords close to the Godthåbsfjord (204-289 $\mu \mathrm{mol}$ photons $\mathrm{m}^{-2} \mathrm{~s}^{-1}$ ) 222 at $2 \mathrm{~m}$ depth during May and June 2013 (Olesen et al., 2015). This experiment also 223 provided the results described in Krause-Jensen et al. (2016).

224 The aquaria were filled with artificial seawater made from distilled water, Reef 225 Crystals ${ }^{\circledR}$ and $\mathrm{NaCl}$ to obtain a similar salinity (30.2 \pm 0.42 , subarctic range: $\left.28.9-31.7\right)$ 226 and alkalinity $\left(2241 \mu \mathrm{mol} \mathrm{kg} \mathrm{SW}{ }^{-1} \pm 31.3\right.$, measured in the sampled area: $1980-2240 \mu \mathrm{mol}$ $227 \mathrm{~kg} \mathrm{SW}^{-1}$ ) as conditions in the field. The artificial seawater was pre-exposed to UV to limit 228 the growth of microorganisms during the experiment. To reach targeted $p \mathrm{CO}_{2}$ levels, air 229 was circulated through soda lime tubes to remove the $\mathrm{CO}_{2}$ present and it was mixed with 230 pure $\mathrm{CO}_{2}$ gas in a bottle with marbles to maximize the mixing surface area. The 231 concentration of air and pure $\mathrm{CO}_{2}$ in the mixing bottle was regulated with mass flow 232 controllers (MFCs, AALBORG GFC-17, US). The targeted $p \mathrm{CO}_{2}$ concentration was 233 continuously supplied to the aquaria through porous bubble curtains. $\mathrm{pH}$ was measured 234 in continuum with $\mathrm{pH}$ electrodes (Omega, PHE-1411) and recorded at 15 min intervals 235 (IKS Aquastar, Germany; for more details see Krause-Jensen et al., 2016). When seawater 236 in the aquaria had reached a stabilized $\mathrm{pH}$ and targeted $p \mathrm{CO}_{2}$ was reached, the same 237 number of tips of $A$. nodosum and $F$. vesiculosus and shoots of $Z$. marina (6 individuals 238 of each species) were attached to the base of the aquaria, with every individual identified 239 with a label. The macrophytes in each of the six aquaria were cycled through a series of 240 random photoperiods (12:12h, 15:9h, 18:6h, 21:3h and 24:0h, light:dark hours), that were 241 run as a whole experimental unit and maintained 3 days at each photoperiod treatment 242 (Fig. 1). Total alkalinity (TA) was measured at the start and end of each photoperiod and interpolated linearly over the 3-days period. Sampled seawater was poisoned with 0.02 $\mathrm{ml}$ of a saturated solution of $\mathrm{HgCl}_{2}$ (Merck, Analar) in order to avoid biological alteration of the sample during storage. TA was determined with a Titrando 808 (Metrohm) by open cell titration as described in Dickson et al., (2007). Certified $\mathrm{CO}_{2}$ seawater reference material (CRM Batch136) from the Andrew Dickson lab at UC San Diego was used to warrant the accuracy of results. TA and $\mathrm{pH}_{\mathrm{NBS}}$ were used to calculate the $\mathrm{CO}_{2}$ concentrations using CO2SYS Pierrot et al., (2006), with dissociation constants from Mehrbach et al., (1973) refitted by Dickson and Millero, (1987) and $\mathrm{HSO}_{4}{ }^{-}$using Dickson, (1990). In between photoperiod treatments, seawater was changed and replaced by seawater pre-treated with $\mathrm{CO}_{2}$ gas at the targeted $p \mathrm{CO}_{2}$ levels.

The photosynthetic capacity of the three macrophyte species was measured through photosynthesis-irradiance curves (PI curves), also known as rapid light curves (RLC), showing the response of the chlorophyll $a$ fluorescence to a range of light intensities (Falkowski and Raven, 2013; Ralph and Gademann, 2005). The measurements were done after 3 days exposure to an experimental photoperiod on two of the six individuals of each species present in two out of three replicated aquaria using Pulse Amplitude Modulation,

259 with a diving-PAM fluorometer (Walz, Germany). The measurements were always done 260 
leaf and $4 \mathrm{~cm}$ above the meristem. On $A$. nodosum and $F$. vesiculosus measurements were done below the youngest bladder.

To avoid excessive manipulation of macrophytes, the measurements were done inside the aquaria. Using a PAM leaf-clip, the tissue, was dark-adapted for $5 \mathrm{~min}$ as done in previous studies (e. g. Anton et al., 2018; Apostolaki et al., 2014; Hendriks et al., 2017) and was illuminated with a series of nine increasing actinic light intensities (from 0 to

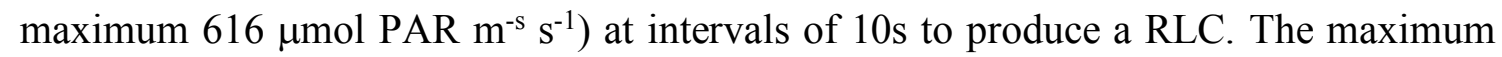
relative electron transport rate $\left(\mathrm{rETR}_{\max }, \mathrm{n}=12\right.$ per species and per photoperiod) was calculated by fitting the RLC data with the non-linear model (Harrison and Platt, 1986; Platt et al., 1982; Ralph and Gademann, 2005):

271

$$
r E T R=r E T R_{\max } \times\left(1-e^{\left(-\alpha \times P A R_{\text {incident }} / r E T R_{\max }\right)}\right)
$$

The photosynthetic parameters rETR $_{\max }$, photosynthetic or quantum efficiency $(\alpha)$ and saturating irradiance $\left(\mathrm{Ik}, \mathrm{Ik}=\mathrm{rETR}_{\max } / \alpha\right.$ ) were estimated by fitting the data of the RLC to Eq. 1 using R version 1.0.44 (R Core Team, 2014). Even though A. nodosum and $Z$. marina showed no asymptotic approximation to the $\mathrm{rETR}_{\max }$ in some cases due to the limited range of actinic light intensities above light saturation (Fig. A1 and A3), rETR max $_{\text {a }}$ could still be estimated from the curvature of the RLC.

\subsection{Statistical analysis}

We evaluated if $\mathrm{CO}_{2}$ (3 levels) and photoperiod (5 levels) had an effect on photosynthetic responses, as represented by $\mathrm{rETR}_{\max }, \alpha$ and $\mathrm{Ik}$, and if such effects were similar or different for the three macrophyte species tested. The experiment was a splitplot design due to restricted randomization for photoperiod, i.e. each level of photoperiod was run separately (whole plot) and without replication. Experimental units (whole plots) consisted of six aquaria that were grouped into 3 levels of $\mathrm{CO}_{2}$ with 2 replicates for each $\mathrm{CO}_{2}$ treatment at each photoperiod (Fig. 1). The experimental units were sub-divided or split into different periods (sub-plots) to test the effects of varying photoperiod. However, aquaria were nested within $\mathrm{CO}_{2}$ treatment, as the same $\mathrm{CO}_{2}$ treatment was applied to the same aquarium for all photoperiods. All three species were randomly sampled for each sub-plot and, consequently, species variation was a factor fully crossed with the two treatment factors. Finally, individual macrophyte specimens within each aquarium were not replaced between different photoperiod levels and constituted a random factor nested within $\mathrm{CO}_{2}$ treatment and aquarium. The following split-plot model (using capital letters for random factors in Eq. 2) was employed for the three photosynthesis variables separately (rETR $\max$ and Ik were log-transformed):

$$
\begin{gathered}
Y_{i j k l}=\mu+\underbrace{c_{i}+A_{l}\left(c_{j}\right)+I_{m}\left(A_{l}\left(c_{j}\right)\right)}_{\text {whole }- \text { plot }}+\underbrace{p_{j}+p_{j} \times c_{i}+P_{j} \times A_{l}\left(c_{j}\right)+P_{j} \times I_{m}\left(A_{l}\left(c_{j}\right)\right)}_{\text {split -plot }} \\
+\underbrace{s_{k}+s_{k} \times c_{i}+s_{k} \times p_{j}+s_{k} \times p_{j} \times c_{i}}_{\text {species variations fixed effects }}
\end{gathered}
$$


where $\mu$ is the overall mean, $c_{j}=\mathrm{CO}_{2}$ treatment, $p_{i}=$ photoperiod, $s_{k}=$ species, $A_{l}=$ aquarium and $I_{m}=$ individual macrophyte specimen. The three main effects $\left(p_{i}, c_{j}\right.$, and $s_{k}$ ) and their interaction were fixed effects, whereas variation among aquaria $\left(A_{l}\right)$ and macrophyte individuals $\left(I_{m}\right)$ and interactions derived from these were random. Marginal means were calculated for all the fixed effects and back-transformed to the geometric mean for the two log-transformed response variables.

The split-plot model is a mixed linear model and was analysed using PROC MIXED in SAS version 9.3. Statistical testing for fixed effects (F-test with Satterthwaite approximation for denominator degrees of freedom) and random effects (Wald Z-test) were carried out at a 5\% significance level. The F-test for fixed effects was partial, i.e. considering the specific contribution of the given effect in addition to all other factors.

\section{Results}

The RLCs (Fig. A1, A2, A3) typically flattened out for all three species around 200 $\mu \mathrm{mol}$ photons $\mathrm{m}^{-2} \mathrm{~s}^{-1}$, but light saturation (Ik) was reached at lower light levels for $F$. vesiculosus and $Z$. marina than $A$. nodosum. Photoinhibition, lowering of photosynthetic rates at higher irradiances, was not detected.

$\mathrm{rETR}_{\max }$ and saturating irradiance (Ik) were significantly different between photoperiods with values increasing progressively up to the $24 \mathrm{~h}$-light photoperiod (Table 1). The largest differences in $\mathrm{rETR}_{\max }$ were found between the $21 \mathrm{~h}$ and $24 \mathrm{~h}$ photoperiod with increases from 20.4 up to $30 \mu \mathrm{mol}$ electrons $\mathrm{m}^{-2} \mathrm{~s}^{-1}$, when all species data was pooled. At the photoperiods of $12 \mathrm{~h}, 15 \mathrm{~h}$ and $18 \mathrm{~h}$ the rETR $_{\max }$ was variable $(21.8,23.5$ and 23.5 $\mu \mathrm{mol}$ electrons $\mathrm{m}^{-2} \mathrm{~s}^{-1}$, respectively when all species data were pooled).

The highest average values of $\mathrm{rETR}_{\max }$ and Ik were found for $A$. nodosum (Fig. 2a, c, Table 1). $\mathrm{rETR}_{\max }$ increased $15 \%$, on average, from $200 \mathrm{ppm}$ of $p \mathrm{CO}_{2}$ to $1000 \mathrm{ppm}$ (from 21.2 to $24.4 \mu \mathrm{mol}$ electrons $\mathrm{m}^{-2} \mathrm{~s}^{-1}$ ) although the effect of the $\mathrm{CO}_{2}$ treatment was not significant (Table 1). The photosynthetic efficiency, $\alpha$, was significantly different between species with higher values for both macroalgae compared to Z. marina (Fig. $2 b$, Table 1). The $\mathrm{CO}_{2}$ effect on $\alpha$ was not significant but a gradual increase of $10 \%$ was observed from 200 to $1000 \mathrm{ppm}$ (Table 1), while Ik did not show an effect of $\mathrm{CO}_{2}$ (Table 1). The interaction effect between the different photoperiods and the species was significant for $\alpha$ and Ik, but not for $\mathrm{rETR}_{\max }$ (Fig. 3, Table 1). Z. marina showed the highest increase in $\mathrm{rETR}_{\max }$ on average from the photoperiod of $12 \mathrm{~h}$ to $24 \mathrm{~h}(10.7 \mu \mathrm{mol}$ electrons $\left.\mathrm{m}^{-2} \mathrm{~s}^{-1}\right)$; followed by A. nodosum $\left(9.9 \mu \mathrm{mol}\right.$ electrons $\left.\mathrm{m}^{-2} \mathrm{~s}^{-1}\right)$ and the lowest increase was observed in $F$. vesiculosus $\left(3.2 \mu \mathrm{mol}\right.$ electrons $\mathrm{m}^{-2} \mathrm{~s}^{-1}$, Fig. 3a).

The interaction effect between $\mathrm{CO}_{2}$ treatments and species was not significant for any of the photosynthetic responses, but $A$. nodosum showed the highest $\mathrm{rETR}_{\max }$ and Ik at 1000 ppm (Fig. 4). The three photosynthetic parameters (rETR $\max , \alpha$ and Ik) showed 
346 indicates that variations associated with using different aquarium and analysis on

347 individual macrophyte specimen were relatively small compared to variations associated

348 with the photosynthetic activity.

\section{Discussion}

Our results showed a significant increase in photosynthetic capacity in response to longer photoperiod, since rETR $_{\max }$ increased from $21 \mathrm{~h}$ to $24 \mathrm{~h}$ for the three species tested after 3 days of incubation. During shorter photoperiods ( $12 \mathrm{~h}$ to $18 \mathrm{~h}$ ) rETR $\mathrm{rax}_{\text {mas }}$ variable and lower than at $24 \mathrm{~h}$ for the three species tested. The $\mathrm{CO}_{2}$-effect tended to be positive but non-significant. Our results showed maximum $\mathrm{rETR}_{\max }$ at continuous daylight for all three species, indicating an increase of their photosynthetic capacity. The responses were variable among species: $Z$. marina and A. nodosum showed the highest increases in $\mathrm{rETR}_{\max }$ with increasing daylight hours whereas the increase of $F$. vesiculosus was smaller. The photosynthetic efficiency, $\alpha$, in both macroalgae was similar and higher than in Z. marina up until the photoperiod of $21 \mathrm{~h}$ was reached. At continuous light, $\alpha$ showed variations both in $A$. nodosum and $F$. vesiculosus.

Along with the increase of its photosynthetic capacity at continuous daylight, our results indicated no stress, as Yield $(\mathrm{Fv} / \mathrm{Fm})$ in $24 \mathrm{~h}$ light for A. nodosum, F. vesiculosus, nor Z. marina was no different from other photoperiods and showed no decreasing trend over time. These results indicate that the three studied macrophytes species could potentially benefit from increased day length, at least on short time scales (as interfered from 3 days of incubation), however $Z$. marina might encounter more difficulties than macroalgae as they expand northward. Indeed, the presence of $Z$. marina in the subarctic is scarce while the two macroalgae form intertidal subarctic belts. Our results for $A$. nodosum agree with those of Strömgren, (1978), using specimen from the North Sea and Norwegian Sea where A. nodosum, Fucus serratus and Pelvetia canaliculate increased its growth up to $24 \mathrm{~h}$ whereas $F$. vesiculosus only increased up to $20 \mathrm{~h}$ of daylight. The small increase in $\mathrm{rETR}_{\max }$ of $F$. vesiculosus compared with the increase of A. nodosum and $Z$. marina at continuous daylight could explain their current presence in the highArctic (Florczyk and Latala, 1989; Hansen and Haugen, 1989). Other species such as Ulva lactuca and Porphyra umbilicalis from the North Sea did not increase their growth at photoperiods greater than $16 \mathrm{~h}$ (Fortes and Lüning, 1980). Reduced photosynthetic rates from 21 to $24 \mathrm{~h}$ daylight in species from the North Sea and Norwegian Sea are likely caused by high photon flux rates leading to photoinhibition, light-induced reduction in the photosynthetic capacity of the macrophytes, to protect the photosynthetic apparatus, suggesting that macrophytes from different latitudes might regulate their photosynthetic rates differently. Moreover, the Antarctic brown alga (Adenoscystis utriculares) showed faster photoinhibition than brown macroalgae of temperate zones (Hanelt, 1996). Photoinhibition might be produced by continuous high irradiances, low temperatures and $\mathrm{CO}_{2}$ limitation (Beer et al., 2014). Before photoinhibition occurs, there are defence mechanisms that down-regulate photosynthesis to dissipate the excess light energy such as the xanthophyll cycle, the Mehler reaction or the use of Carbon Concentration 
390 Mechanisms (CCMs). Under conditions of $\mathrm{CO}_{2}$-limitation and excess light energy, the

391 Mehler reaction diverts the excess of electrons towards the production of $\mathrm{H}_{2} \mathrm{O}_{2}$ and

392 ultimately water. However, the Mehler reaction cannot be detected by PAM fluorometry

393 (Beer et al., 2014). $\mathrm{CO}_{2}$-limitation and excess light energy also might lead into the use of

$394 \mathrm{CCMs}$, increasing $\mathrm{CO}_{2}$ concentration inside the cell and raising the use of energy. In our

395 study, $\mathrm{CO}_{2}$ concentration was not limiting, and neither were light or temperature. We

396 chose to use PAM fluorometry, despite its shortcomings of only assessing part of the

397 photosynthetic response, because it is a non-invasive technique that does not overly stress

398 or damage the macrophyte, which is crucial in experiments with repeated measures over

399 some period of time.

$400 \quad \mathrm{rETR}_{\max }$ and Ik of A. nodosum and Z. marina increased slightly, yet insignificantly, in

401 response to increasing $\mathrm{CO}_{2}$, while $F$. vesiculosus did not show any response. Other studies

402 show that the arctic macroalgae Alaria esculenta was positively affected by increased

$403 \mathrm{CO}_{2}$, showing an increase of $\mathrm{rETR}_{\max }, \alpha$ and Ik along with increasing growth rates, while

404 the species Desmarestia aculeata responded by decreasing rETR max $_{\text {ax }}$ and growth rates

405 (Iñiguez et al., 2016). The small response of $A$. nodosum agrees with the notion that this

406 macroalgae is not $\mathrm{CO}_{2}$-saturated at ambient levels and diffusive entry of $\mathrm{CO}_{2}$ seemed to

407 be required (Koch et al., 2013; Surif and Raven, 1989), while the absence of response of

408 F. vesiculosus might indicate that it is $\mathrm{CO}_{2}$-saturated at ambient levels (Koch et al., 2013;

409 Raven and Osmond, 1992) and had high capacity for DIC uptake by non-diffusive

410 mechanisms (Mercado et al., 2009). Increased $\mathrm{CO}_{2}$ might benefit subarctic $A$. nodosum

411 because it is not currently $\mathrm{CO}_{2}$-saturated and the diffusive entry of $\mathrm{CO}_{2}$ or $\mathrm{CCMs}$ based

412 on $\mathrm{HCO}_{3}{ }^{-}$usage are required (Johnston and Raven, 1986; Koch et al., 2013; Surif and

413 Raven, 1989), while $F$. vesiculosus was not affected by increased $\mathrm{CO}_{2}$ probably due to its

414 currently $\mathrm{CO}_{2}$-saturated stage and its capacity for non-diffusive mechanisms (Koch et al.,

415 2013; Raven and Osmond, 1992). The seagrass Z. marina can be either $\mathrm{CO}_{2}$-saturated or

416 -limited at ambient levels (Koch et al., 2013). We observed a positive response, though

417 non-significant of $Z$. marina to increased $\mathrm{CO}_{2}$, in line with $\mathrm{CO}_{2}$-stimulation of seagrass

418 photosynthesis observed in other regions (Koch et al., 2013).

419 Our results show a non-significant interaction between increased $\mathrm{CO}_{2}$ concentration

420 and increased photoperiods. $\mathrm{CO}_{2}$-limitating environments generally increase the use of

421 CCMs, producing photoinhibition and decreasing the photosynthetic activity and growth.

422 Excess of light irradiance also might produce photoinhibition and a decrease of

423 photosynthetic activity. Our results indicate that continuous daylight at their natural

424 submerged irradiance (111 $\pm 5 \mu \mathrm{mol}$ photons $\mathrm{m}^{-\mathrm{s}} \mathrm{s}^{-1}$ of PAR) lead to a positive

425 photosynthetic response of the three species tested while no significant response was

426 observed to increased $\mathrm{CO}_{2}$.

427

428

429

\section{Conclusions}

430 Our results suggest that a continuous photoperiod, characteristic of Arctic summers, 431 may benefit the subarctic macrophytes tested in this study, increasing their photosynthetic 432 activity. A. nodosum, F. vesiculosus and Z. marina, hence, take advantage of increased 433 daylength during the Arctic summer as they migrate poleward with decreasing ice cover. 
434 As they expand northward, they will probably be able to successfully cope with $24 \mathrm{~h}$ of 435 darkness during the Arctic winter since they are already present at $69.7^{\circ} \mathrm{N}$ (A. nodosum, 436 reviewed by Marbà et al., 2017), $75^{\circ}$ N (F. vesiculosus, Florczyk and Latala, 1989; 437 Hansen and Haugen, 1989) and $70^{\circ} \mathrm{N}$ (Z. marina, reviewed by Olesen et al., 2015), and 438 thus exposed to photoperiods of long daylight and darkness. Nevertheless, further 439 research is needed on the interactive effects of day length and increased $\mathrm{CO}_{2}$ with 440 nutrients availability, salinity and light intensities on photosynthesis of arctic and 441 subarctic macrophyte. Melting ice and coastal erosion leads to reduced light penetration 442 due to increased turbidity altering how macrophytes are distributed (Traiger and Konar, 443 2018) and been negatively affected (Bonsell and Dunton, 2018; Filbee-Dexter et al., 444 2019). Freshwater accumulation is reducing nutrient inventories in the arctic water 445 column (Coupel et al., 2015; Yun et al., 2016) probably due to strong stratification 446 (McLaughlin and Carmack, 2010; Post et al., 2013). Gordillo et al., (2006) showed a high 447 resilience to nutrient-limitation of many arctic macrophytes. Our results demonstrate that 448 continuous photoperiod stimulates the photosynthesis of the subarctic macrophytes tested 449 and support the forecasted poleward expansion of subarctic vegetation into the high450 Arctic (Krause-Jensen and Duarte, 2014). However, the spread of existing Arctic 451 macroalgae with climate change needs to be further studied focussing on the interactive 452 effects of long day length with $\mathrm{CO}_{2}$, nutrients availability, salinity and light intensities.

453

454

\section{Acknowledgments}

456 This research was funded by the Danish Environmental Protection Agency within the 457 Danish Cooperation for Environment in the Arctic program. We thank J. Thyrring for his 458 help on the field, J. Baldrich and E. Pérez León for their assistance in the laboratory; A. 459 Lázaro, G. Escribano-Ávila, A. Payo-Payo and L. Cayuela for helpful comments on 460 mixed models. We also thank J. Flexas and C. Íñiguez for sharing their knowledge on 461 plant physiology, and J. Terrados for the logistic support. M.S.-M. was supported by a 462 Fundación "La Caixa" fellowship and the unemployment benefit of Spanish Ministry of 463 Labour, Migrations and Social Security. I.E.H. was supported by grant RYC-2014464 15147, co-funded by the Conselleria d'Innovació, Recerca i Turisme of the Balearic 465 Government (Pla de ciència, tecnologia, innovació i emprenedoria 2013-2017) and the 466 Spanish Ministry of Economy, Industry and Competitiveness.

\section{References}

470

Anton, A., Hendriks, I.E., Marbà, N., Krause-Jensen, D., Garcias-Bonet, N., Duarte, C.M., 2018. Iron Deficiency in Seagrasses and Macroalgae in the Red Sea Is Unrelated to Latitude and Physiological Performance. Front. Mar. Sci. 5, 1-14. https://doi.org/10.3389/fmars.2018.00074

475 Apostolaki, E.T., Vizzini, S., Hendriks, I.E., Olsen, Y.S., 2014. Seagrass ecosystem 
response to long-term high $\mathrm{CO}_{2}$ in a Mediterranean volcanic vent. Mar. Environ. Res. 99, 9-15. https://doi.org/10.1016/j.marenvres.2014.05.008

Bates, N.R., Moran, S.B., Hansell, D.A., Mathis, J.T., 2006. An increasing $\mathrm{CO}_{2}$ sink in the Arctic Ocean due to sea-ice loss. Geophys. Res. Lett. 33, 1-7. https://doi.org/10.1029/2006GL027028

Beer, S., Björk, M., Beardall, J., 2014. Photosynthesis in the marine environment. John Wiley \& Sons.

Beer, S., Rehnberg, J., 1997. The acquisition of inorganic carbon by the seagrass Zostera marina. Aquat. Bot. 56, 277-283.

Berge, J., Johnsen, G.H., Nilsen, F., Bjørn, G., Slagstad, D., 2005. Ocean temperature oscillations enable reappearance of blue mussels Mytilus edulis in Svalbard after a 1000 year absence. Mar. Ecol. Prog. Ser. 303, 167-175. https://doi.org/10.3354/meps303167

Bonsell, C., Dunton, K.H., 2018. Long-term patterns of benthic irradiance and kelp production in the central Beaufort sea reveal implications of warming for Arctic inner shelves. Prog. Oceanogr. 162, 160-170. https://doi.org/10.1016/j.pocean.2018.02.016

Bowes, G., 1985. Pathways of $\mathrm{CO}_{2}$ fixation by aquatic organisms. Inorg. carbon uptake by Aquat. Photosynth. Org. 187-210.

Bowes, G., Salvuci, M.E., 1989. Plasticity in the photosynthetic carbon metabolism of submersed aquatic macrophytes. Aquat Bot 34, 233-266.

Coupel, P., Ruiz-Pino, D., Sicre, M.A., Chen, J., Lee, S.H., Schiffrine, N., Li, H.L., Gascard, J.C., 2015. The impact of freshening on phytoplankton production in the Pacific Arctic Ocean. Prog. Oceanogr. 131, 113-125. https://doi.org/10.1016/j.pocean.2014.12.003

Dickson, A.G., 1990. Standard potential of the reaction: $\mathrm{AgCl}(\mathrm{s})+1 / 2 \mathrm{H}_{2}(\mathrm{~g})=\mathrm{Ag}$ (s) $+\mathrm{HCl}(\mathrm{aq})$, and and the standard acidity constant of the ion $\mathrm{HSO}_{4}{ }^{-}$in synthetic sea water from 273.15 to 318.15 K. J. Chem. Thermodyn. 22, 113127.

Dickson, A.G., Millero, F.J., 1987. A comparison of the equilibrium constants for the dissociation of carbonic acid in seawater media. Deep Sea Res. Part A. Oceanogr. Res. Pap. 34, 1733-1743.

Dickson, A.G., Sabine, C.L., Christian, J.R., 2007. Guide to best practices for ocean C02, PICES Special Publication. North Pacific Marine Science Organization, Sidney, British Columbia.

Duarte, C.M., Cebrián, J., 1996. The fate of marine autotrophic production. Limnol. Oceanogr. 41, 1758-1766. https://doi.org/10.4319/lo.1996.41.8.1758

Engel, A., Piontek, J., Grossart, H.P., Riebesell, U., Schulz, K.G., Sperling, M., 2014. Impact of $\mathrm{CO}_{2}$ enrichment on organic matter dynamics during nutrient induced coastal phytoplankton blooms. J. Plankton Res. 36, 641-657. https://doi.org/10.1093/plankt/fbt125

Falkowski, P.G., Raven, J.A., 2013. Aquatic photosynthesis, Freshwater Biology. Princeton University Press. https://doi.org/10.1016/j.bmcl.2011.05.118 
Filbee-Dexter, K., Wernberg, T., Fredriksen, S., Norderhaug, K.M., Foldager, M., 2019. Arctic kelp forests : Diversity , resilience and future. Glob. Planet. Change 172,1-14. https://doi.org/10.1016/j.gloplacha.2018.09.005

Florczyk, I., Latala, A., 1989. The phytobenthos of the Hornsund fiord, SW Spitsbergen. Polar Res. 7, 29-41. https://doi.org/10.1111/j.17518369.1989.tb00602.x

Fortes, M.D., Lüning, K., 1980. Growth rates of North Sea macroalgae in relation to temperature, irradiance and photoperiod. Helgoländer Meeresuntersuchungen 34, 15-29.

Fransson, A., Chierici, M., Nojiri, Y., 2009. New insights into the spatial variability of the surface water carbon dioxide in varying sea ice conditions in the Arctic Ocean. Cont. Shelf Res. 29, 1317-1328. https://doi.org/10.1016/j.csr.2009.03.008

Fredriksen, S., Bartsch, I., Wiencke, C., 2014. New additions to the benthic marine flora of Kongsfjorden, western Svalbard, and comparison between 1996/1998 and 2012/2013. Bot. Mar. 57, 203-216. https://doi.org/10.1515/bot-20130119

Giordano, M., Beardall, J., Raven, J.A., 2005. $\mathrm{CO}_{2}$ concentrating mechanisms in algae: mechanisms, environmental modulation, and evolution. Annu. Rev. Plant Biol. 56, 99-131. https://doi.org/10.1146/annurev.arplant.56.032604.144052

Giordano, M., Maberly, S.C., 1989. Distribution of carbonic anhydrase in British marine macroalgae. Oecologia 81, 534-539. https://doi.org/10.1007/BF00378965

Gordillo, F.J.L., Aguilera, J., Jiménez, C., 2006. The response of nutrient assimilation and biochemical composition of Arctic seaweeds to a nutrient input in summer. J. Exp. Bot. 57, 2661-2671. https://doi.org/10.1093/jxb/erl029

Hanelt, D., 1996. Photoinhibition of photosynthesis in marine macroalgae. Sci. Mar. 60, 243-248.

Hansen, J.R., Haugen, I., 1989. Some observations of intertidal communities on Spitsbergen $\left(79^{\circ} \mathrm{N}\right)$, Norwegian Arctic. Polar Res. 7, 23-27. https://doi.org/10.1111/j.1751-8369.1989.tb00601.x

Harrison, W.G., Platt, T., 1986. Photosynthesis-irradiance relationship in polar and temperate phytoplankton populations. Polar Biol. 5, 153-164.

Hein, M., Sand-Jensen, K., 1997. $\mathrm{CO}_{2}$ increases oceanic primary production. Nature 388, 526-527.

Hendriks, I.E., Duarte, C.M., Marbà, N., Krause-Jensen, D., 2017. pH gradients in the diffusive boundary layer of subarctic macrophytes. Polar Biol. 1-6. https://doi.org/10.1007/s00300-017-2143-y

Holbrook, G.P., Beer, S., Spencer, W.E., Reiskind, J.B., Davis, J.S., Bowes, G., 1987. Photosynthesis in marine macroalgae: evidence for carbon limitation. Can. J. Bot. 66, 577-582.

Holding, J.M., Duarte, C.M., Sanz-Martín, M., Mesa, E., Arrieta, J.M., Chierici, M., Hendriks, I.E., García-Corral, L.S., Regaudie-De-Gioux, A., Delgado-Huertas, A., 
Reigstad, M., Wassmann, P.F., Agustí, S., 2015. Temperature dependence of $\mathrm{CO}_{2}$-enhanced primary production in the European Arctic Ocean. Nat. Clim. Chang. 8-11. https://doi.org/10.1038/nclimate2768

Hoppe, C.J.M., Holtz, L.M., Trimborn, S., Rost, B., 2015. Ocean acidification decreases the light-use efficiency in an Antarctic diatom under dynamic but not constant light. New Phytol. 207, 159-171. https://doi.org/10.1111/nph.13334

Hoppe, C.J.M., Wolf, K.K.E., Schuback, N., Tortell, P.D., Rost, B., 2018. Compensation of ocean acidification effects in Arctic phytoplankton assemblages. Nat. Clim. Chang. 8, 529-533. https://doi.org/10.1038/s41558-018-0142-9

Hoppe, J.C.M., Schuback, N., Semeniuk, D.M., Maldonado, M.T., Rost, B., 2017. Functional Redundancy Facilitates Resilience of Subarctic Phytoplankton Assemblages toward Ocean Acidification and High High Irradiance. Front. Mar. Sci. 4, 1-14. https://doi.org/10.3389/fmars.2017.00229

Hurd, C.L., Hepburn, C.D., Currie, K.I., Raven, J.A., Hunter, K.A., 2009. Testing the effects of ocean acidification on algal metabolism: Considerations for experimental designs. J. Phycol. 45, 1236-1251. https://doi.org/10.1111/j.1529-8817.2009.00768.x

Iñiguez, C., Carmona, R., Lorenzo, M.R., Niell, F.X., Wiencke, C., Gordillo, F.J.L., 2016. Increased $\mathrm{CO}_{2}$ modifies the carbon balance and the photosynthetic yield of two common Arctic brown seaweeds: Desmarestia aculeata and Alaria esculenta. Polar Biol. 39, 1979-1991. https://doi.org/10.1007/s00300-0151724-x

Iñiguez, C., Heinrich, S., Harms, L., Gordillo, F.J.L., 2017. Increased temperature and CO2 alleviate photoinhibition in Desmarestia anceps: from transcriptomics to carbon utilization. J. Exp. Bot. https://doi.org/10.1093/jxb/erx164

IPCC Panel, 2014. Climate Change 2014: Synthesis Report, Contributi. ed. Geneva, Switzerland.

Johnston, A.M., Raven, J.A., 1986. The utilization of bicarbonate ions by the macroalga Ascophyllum nodosum (L.) Le Jolis. Plant. Cell Environ. 9, 175-184.

Kjesbu, O.S., Bogstad, B., Devine, J.A., Gjøsæter, H., Howell, D., Ingvaldsen, R.B., Nash, R.D.M., Skjæraasen, J.E., 2014. Synergies between climate and management for Atlantic cod fisheries at high latitudes. Proc. Natl. Acad. Sci. 111, 3478-3483. https://doi.org/10.1073/pnas.1316342111

Koch, M., Bowes, G., Ross, C., Zhang, X.H., 2013. Climate change and ocean acidification effects on seagrasses and marine macroalgae. Glob. Chang. Biol. 19, 103-132. https://doi.org/10.1111/j.1365-2486.2012.02791.x

Krause-Jensen, D., Duarte, C.M., 2014. Expansion of vegetated coastal ecosystems in the future Arctic. Front. Mar. Sci. 1, 1-10. https://doi.org/10.3389/fmars.2014.00077

Krause-Jensen, D., Marbà, N., Olesen, B., Sejr, M.K., Christensen, P.B., Rodrigues, J., Renaud, P.E., Balsby, T.J.S., Rysgaard, S., 2012. Seasonal sea ice cover as principal driver of spatial and temporal variation in depth extension and annual production of kelp in Greenland. Glob. Chang. Biol. 18, 2981-2994. https://doi.org/10.1111/j.1365-2486.2012.02765.x 
Krause-Jensen, D., Marbà, N., Sanz-Martín, M., Hendriks, I.E., Thyrring, J., Carstensen, J., Sejr, M.K., Duarte, C.M., 2016. Long photoperiods sustain high pH in Arctic kelp forests. Sci. Adv. 2, 1-8. https://doi.org/10.1126/sciadv.1501938

Madsen, T. V., Sand-Jensen, K., 1991. Photosynthetic carbon assimilation in aquatic macrophytes. Aquat. Bot. 41.

Marbà, N., Krause-Jensen, D., Olesen, B., Christensen, P.B., Merzouk, A., Rodrigues, J., Wegeberg, S., Wilce, R.T., 2017. Climate change stimulates the growth of the intertidal macroalgae Ascophyllum nodosum near the northern distribution limit. Ambio 46, 119-131. https://doi.org/10.1007/s13280-016-0873-7

McLaughlin, F.A., Carmack, E.C., 2010. Deepening of the nutricline and chlorophyll maximum in the Canada Basin interior, 2003-2009. Geophys. Res. Lett. 37, 15. https://doi.org/10.1029/2010GL045459

McMinn, A., Martin, A., Ryan, K., 2010. Phytoplankton and sea ice algal biomass and physiology during the transition between winter and spring (McMurdo Sound, Antarctica). Polar Biol. 33, 1547-1556. https://doi.org/10.1007/s00300-0100844-6

Mehrbach, C., Culberson, C.H., Hawley, J.E., Pytkowicx, R.M., 1973. Measurement of the apparent dissociation constants of carbonic acid in seawater at atmospheric pressure. Limnol. Oceanogr. 18, 897-907.

Meire, L., Søgaard, D.H., Mortensen, J., Meysman, F.J.R., Soetaert, K., Arendt, K.E., Juul-Pedersen, T., Blicher, M.E., Rysgaard, S., 2015. Glacial meltwater and primary production are drivers of strong $\mathrm{CO}_{2}$ uptake in fjord and coastal waters adjacent to the Greenland Ice Sheet. Biogeosciences 12, 2347-2363. https://doi.org/10.5194/bg-12-2347-2015

Mercado, J.M., de los Santos, C.B., Lucas Pérez-Llorens, J., Vergara, J.J., 2009. Carbon isotopic fractionation in macroalgae from Cádiz Bay (Southern Spain): Comparison with other bio-geographic regions. Estuar. Coast. Shelf Sci. 85, 449-458. https://doi.org/10.1016/j.ecss.2009.09.005

Mercado, J.M., Gordillo, F., 2011. Inorganic carbon acquisition in algal communities: are the laboratory data relevant to the natural ecosystems? Photosynth. Res. 109, 257-67. https://doi.org/10.1007/s11120-011-9646-0

Olesen, B., Krause-Jensen, D., Marbà, N., Christensen, P.B., 2015. Eelgrass Zostera marina in subarctic Greenland: Dense meadows with slow biomass turnover in cold waters. Mar. Ecol. Prog. Ser. 518, 107-121. https://doi.org/10.3354/meps11087

Pierrot, D., Lewis, E.R., Wallace, D.W.R., 2006. MS excel program developed for $\mathrm{CO}_{2}$ system calculations. Carbon dioxide information analysis center, Oak Ridge National Laboratory. US Department of Energy, Oak Ridge, Tennessee.

Platt, T., Harrison, W.G., Irwin, B., Horne, E.P., Gallegos, C.L., 1982. Photosynthesis and photoadaptation of marine phytoplankton in the Arctic. Deep Sea Res. 29, 1159-1170.

Post, E., Bhatt, U.S., Bitz, C.M., Brodie, J.F., Fulton, T.L., Hebblewhite, M., Kerby, J., Kutz, S.J., Stirling, I., Walker, D.A., 2013. Ecological consequences of sea-ice 

decline. Science (80-. ). 341, 519-525.

R Core Team, 2014. R: A language and environment for statistical computing. $R$ Foundation for Statistical Computing, Vienna, Austria. 2013.

Ralph, P.J., Gademann, R., 2005. Rapid light curves: A powerful tool to assess photosynthetic activity. Aquat. Bot. 82, 222-237. https://doi.org/10.1016/j.aquabot.2005.02.006

Raven, J.A., Johnston, A.M., Kübler, J.E., Korb, R., McInroy, S.G., Handley, L.L., Scrimgeour, C.M., Walker, D.I., 2002a. Mechanistic interpretation of carbon isotope discrimination by marine macroalgae and seagrasses. Funct. Plant Biol. 29, 335-378. https://doi.org/10.1071/PP01201

Raven, J.A., Johnston, A.M., Kübler, J.E., Korb, R., McInroy, S.G., Handley, L.L., Scrimgeour, C.M., Walker, D.I., Beardall, J., Clayton, M.N., Vanderklift, M., Fredriksen, S., Dunton, K.H., 2002b. Seaweeds in cold seas: Evolution and carbon acquisition. Ann. Bot. 90, 525-536. https://doi.org/10.1093/aob/mcf171

Raven, J.A., Osmond, C.B., 1992. Inorganic C acquisition processes and their ecological significance in inter- and sub-tidal macroalgae of North Carolina. Funct. Ecol. 6, 41-47.

Rysgaard, S., Bendtsen, J., Pedersen, L.T., Ramløv, H., Glud, R.N., 2009. Increased $\mathrm{CO}_{2}$ uptake due to sea ice growth and decay in the Nordic Seas. J. Geophys. Res. 114, C09011. https://doi.org/10.1029/2008JC005088

Sand-Jensen, K., Gordon, D.M., 1984. Differential ability of marine and freshwater macrophytes to utilize $\mathrm{HCO}^{3-}$ and $\mathrm{CO}_{2}$. Mar. Biol. 80, 247-253. https://doi.org/10.1038/470444a

Silva, J., Santos, R., Calleja, M.L., Duarte, C.M., 2005. Submerged versus air-exposed intertidal macrophyte productivity: from physiological to community-level assessments. J. Exp. Mar. Bio. Ecol. 317, 87-95. https://doi.org/10.1016/j.jembe.2004.11.010

Sorte, C.J.B., Williams, S.L., Carlton, J.T., 2010. Marine range shifts and species introductions: Comparative spread rates and community impacts. Glob. Ecol. Biogeogr. 19, 303-316. https://doi.org/10.1111/j.1466-8238.2009.00519.x

Strömgren, T., 1978. The effect of photoperiod on the length growth of five species of intertidal fucales. Sarsia 63, 155-157.

Surif, M.B., Raven, J.A., 1989. Exogenous inorganic carbon sources for photosynthesis in seawater by members of the Fucales and the Laminariales (Phaeophyta): ecological and taxonomic implications. Oecologia 78, 97-105. https://doi.org/10.1007/BF00377203

Takahashi, T., Sutherland, S.C., Wanninkhof, R., Sweeney, C., Feely, R.A., Chipman, D.W., Hales, B., Friederich, G., Chavez, F., Sabine, C., Watson, A., Bakker, D.C.E., Schuster, U., Metzl, N., Yoshikawa-Inoue, H., Ishii, M., Midorikawa, T., Nojiri, Y., Körtzinger, A., Steinhoff, T., Hoppema, M., Olafsson, J., Arnarson, T.S., Tilbrook, B., Johannessen, T., Olsen, A., Bellerby, R., Wong, C.S., Delille, B., Bates, N.R., de Baar, H.J.W., 2009. Climatological mean and decadal change in surface ocean $p \mathrm{CO}_{2}$, and net sea-air $\mathrm{CO}_{2}$ flux over the global oceans. Deep. Res. Part II Top. 

Stud. Oceanogr. 56, 554-577. https://doi.org/10.1016/j.dsr2.2008.12.009

Traiger, S.B., Konar, B., 2018. Journal of Experimental Marine Biology and Ecology Mature and developing kelp bed community composition in a glacial estuary. J. Exp. Mar. Bio. Ecol. 501, 26-35. https://doi.org/10.1016/j.jembe.2017.12.016

Velez Ramirez, A.I., Ieperen, W. van, Vreugdenhill, D., Millenaar, F.F., 2011. Plants under continuous light. Trends Plant Sci. 16, 310-318. https://doi.org/Doi 10.1016/J.Tplants.2011.02.003

Wang, M., Overland, J.E., 2009. A sea ice free summer Arctic within 30 years? Geophys. Res. Lett. 36, 2-6. https://doi.org/10.1029/2009GL037820

Weslawski, J.M., Wiktor, J., Kotwicki, L., 2010. Increase in biodiversity in the arctic rocky littoral, Sorkappland, Svalbard, after 20 years of climate warming. Mar. Biodivers. 40, 123-130. https://doi.org/10.1007/s12526-010-0038-z

Wilce, R., Dunton, K.H., 2014. The boulder Patch (North Alaska, Beaufort Sea) and its benthic algal flora. Arctic 67, 43-56. https://doi.org/10.14430/arctic4360

Wulff, A., Iken, K., Quartino, M.L., Al-Handal, A., Wiencke, C., Clayton, M.N., 2009. Biodiversity, biogeography and zonation of marine benthic micro- and macroalgae in the Arctic and Antarctic. Bot. Mar. 52, 491-507. https://doi.org/10.1515/BOT.2009.072

Yun, M.S., Whitledge, T.E., Stockwell, D., Son, S.H., Lee, J.H., Park, J.-W., Lee, S.H., 2016. Primary production in the Chukchi Sea with potential effects of freshwater content. Biogeosciences 13, 737-749. https://doi.org/10.5194/bg-13-737-2016

Zeebe, R.E., 2012. History of seawater carbonate chemistry, atmospheric $\mathrm{CO}_{2}$, and ocean acidification. Annu. Rev. Earth Planet. Sci. 40, 141-165. https://doi.org/10.1146/annurev-earth-042711-105521 


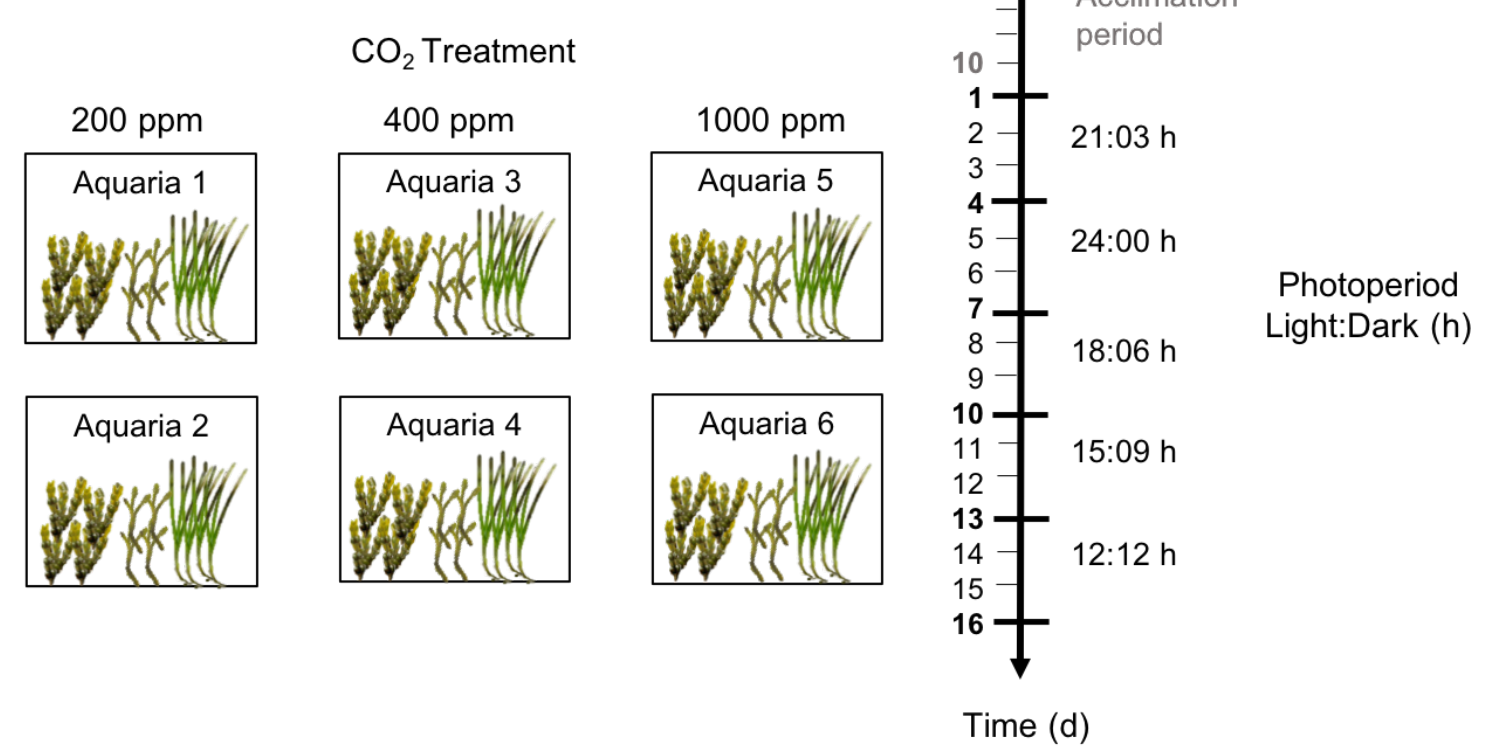

Figure 1: Experimental set-up, analysed with a split-plot model, where specimens of Fucus vesiculosus, Ascophyllum nodosum and Zostera marina were placed into replicated aquaria. After the acclimation period, the $\mathrm{CO}_{2}$ treatments were applied throughout the experiment and light treatments (i.e. photoperiods) were changed every three days.

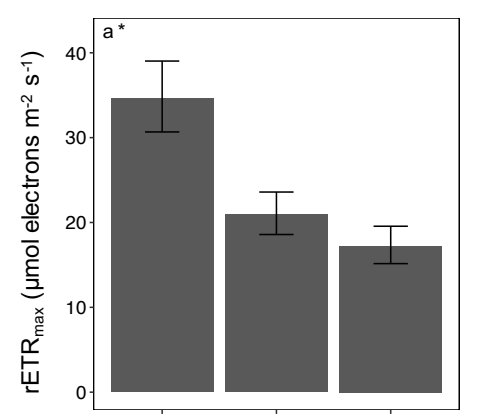

A. nodosum F. vesiculosus Z. marina
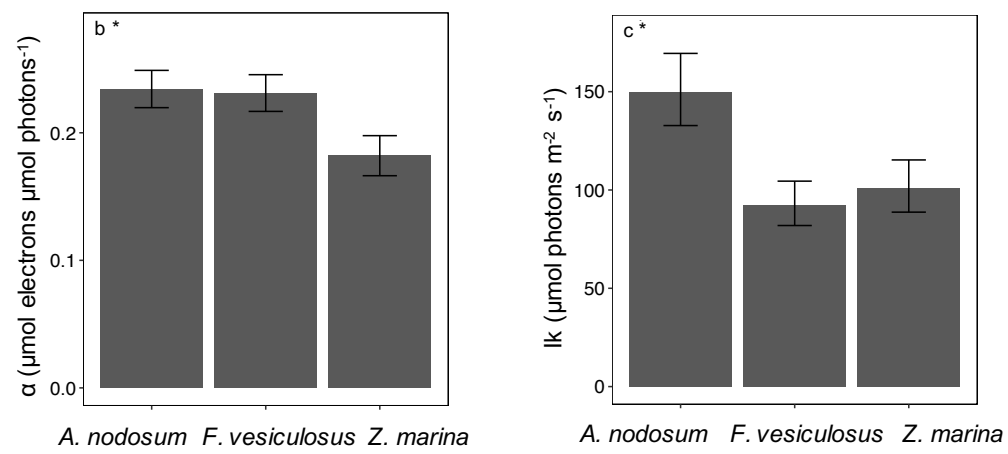

748 Figure 2: Estimated means of $\mathrm{rETR}_{\max }$, and saturating irradiance, $\mathrm{Ik}$ (a, b, c, respectively) as calculated for different species (Ascophyllum nodosum, Fucus vesiculosus and Zostera marina) as the average of the levels of daylight and the $p \mathrm{CO}_{2}$ treatments. Significance is indicated with an asterisk $(\mathrm{p}<0.05)$. Error bars mark standard errors of the means. 

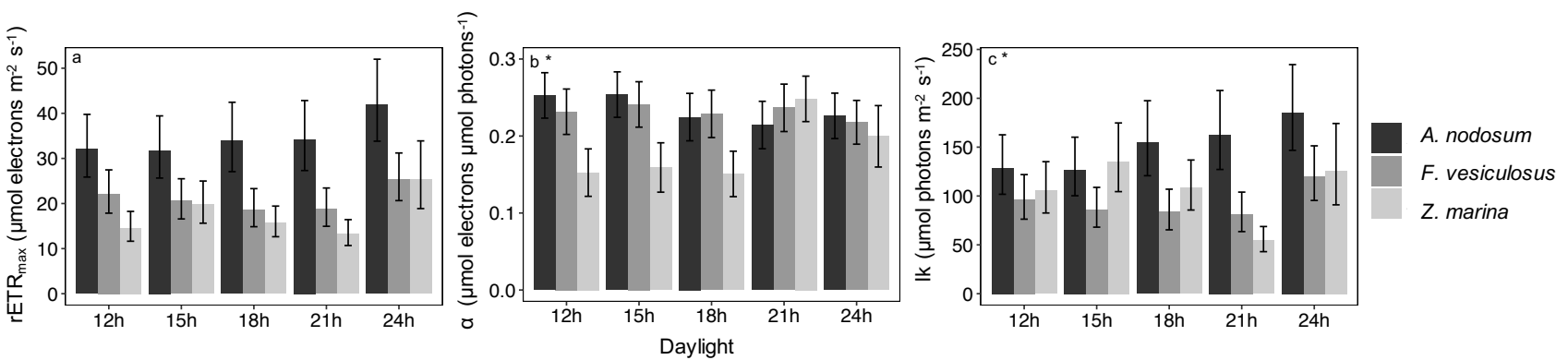

Figure 3: Estimated means of $\mathrm{rETR}_{\max }$, (a) $\alpha$ (b) and saturating irradiance, Ik (c) for different combinations of photoperiod and species (Ascophyllum nodosum, Fucus vesiculosus and Zostera marina), i.e. $s_{k} \times p_{j}$ in the mixed model. Significance of the interaction is indicated with an asterisk $(\mathrm{p}<0.05)$. Error bars mark standard errors of the means.

762

763

764

765

766
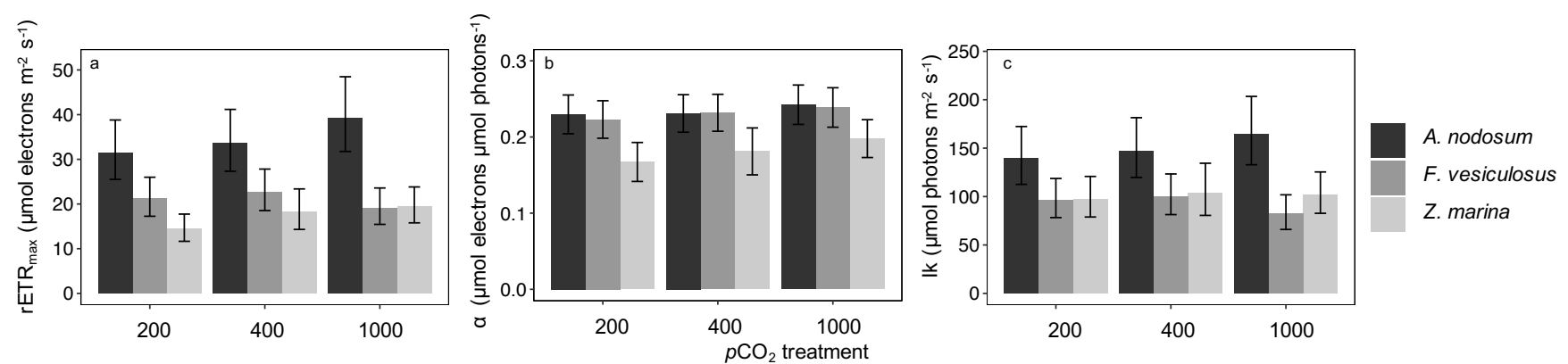

Figure 4: Estimated means of $\mathrm{rETR}_{\max }(\mathrm{a}), \alpha(\mathrm{b})$ and saturating irradiance, Ik (c) for different combinations of $p \mathrm{CO}_{2}$ treatments and species (Ascophyllum nodosum in black, Fucus vesiculosus in dark grey and Zostera marina in light grey), i.e. $s_{k} \times c_{i}$ in the mixed model. Significance of the interaction is indicated with an asterisk $(p<0.05)$ (none of them). Error bars mark standard errors of the means. 
779 Table 1: Statistical tests of the fixed effects for the three photosynthetic responses. 780 Denominator degrees of freedom was calculated with Satterthwaite's approximation. 781 Asterisk on the effect column indicates the interaction between factors while asterisk on 782 the $p$-value column indicate the significance $(\mathrm{p}<0.05)$

783

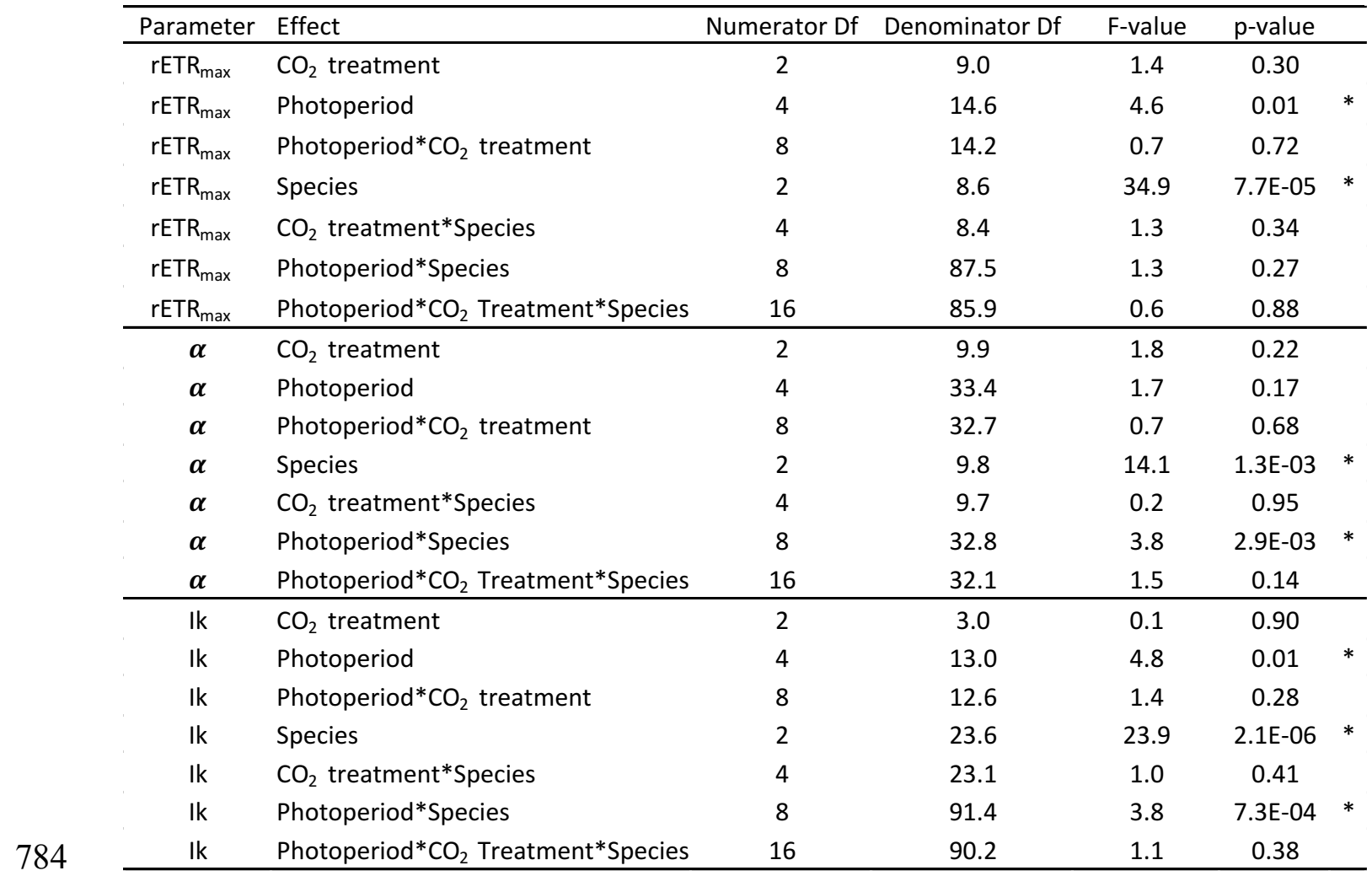

